\title{
Ragam dan Unsur Spiritualitas pada Ilustrasi Naskah Nusantara 1800-1900-an
}

\author{
Nuning Damayanti \& Haryadi Suadi \\ KK Seni Rupa - Fakultas Senirupa dan Desain ITB
}

\begin{abstract}
Abstrak. A civilized society is a society who respects the culture of its predecessors and their philosophy of life, including the inherited artifacts that represent cultural values. Accordingly, the cultural development of a society can be traced and valued from its traditional artifact, such as an ancient drawing/old illustration that passed from the older generation. Aside of its economical values, ancient drawing/old illustration is a cultural product that serves as an object of visual language or visual communication.
\end{abstract}

Before script and writing were established, drawings were used by people from thousands years ago to establish communication. The discovery of pictures in the prehistoric caves is considered as the beginning of drawing tradition towards modern illustration. Yet, the discovery of scripts and writing devalue the tradition of drawing, although it is believed that pictures worth to be the simplest and the most effective communication among human. This research tried to identify how an ancient illustration/drawing is used as a mean to communicate, as well as understanding the society who created it. A hermeneutic reasoning was employed to explain the visuals of ancient illustration/ pictures. Illustrations/pictures from the old Java and Bali traditional visual arts until the first year of the $20^{\text {th }}$ century were used as object of analyses. It was assumed that the selected objects carry visual communication means and spiritualism content that could be elaborated more, and thus provide rich understandings to learn from.

Keywords: illustration; Indonesian art; spiritualism; visual language.

\section{Pendahuluan}

Budaya Indonesia tidak lepas dari dinamika dan perkembangan yang disebabkan oleh arus budaya modern. Dekade terakhir abad ini berada dalam dua konteks yang mewarnai dan membentuk sosok budaya masa kini yaitu proses modernisasi dan globalisasi. Ide-ide, pola prilaku dan kepranataan saling bersilangan dan berbenturan serta bersintesis yang menghasilkan unsur 'budaya baru'. Perkembangan kesenian Indonesia juga mengalami dinamika, dalam berbagai aspek akibat interaksi budaya tersebut.

Received October $21^{\text {st }} 2006$, Revised January $8^{\text {th }} 2007$, Accepted for publication March $1^{\text {st }} 2007$. 
Salah satu bentuk kesenian klasik Indonesia yang mengalami dinamisasi tersebut adalah ilustrasi Nusantara. Awalnya tradisi ilustrasi telah berkembang sejak zaman Hindu dan mencapai puncaknya sebagai ekspresi seni klasik di Jawa dan Bali, sedangkan bentuk seni klasik yang bercorak Islam tercapai di beberapa daerah kekuasaan raja-raja Islam, seperti di Sumatera, Jawa, Madura dan daerah kepulauan Maluku. Bentuk seni klasik yang bercorak Islam ini merupakan pengembangan tradisi seni rupa Indonesia-Hindu yang disesuaikan dengan kebutuhan kebudayaan Islam pada waktu itu.

Penciptaan benda seni tradisi selalu memuat nilai-nilai filosofi hidup masyarakat penciptanya, karena selalu disesuaikan dengan kebutuhan hidupnya agar benda tersebut dapat dipergunakan sesuai dengan fungsi dan tujuan benda itu diciptakan. Demikian pula gambar atau ilustrasi pada naskah-naskah Nusantara memiliki aspek fungsi sosial tertentu. Ilustrasi pada masa lalu yang melengkapi naskah, hakikatnya memuat ajaran-ajaran tentang filsafat hidup, tata cara adat istiadat masyarakat setempat yang disesuaikan dengan sistim kepercayaan yang dianut.

\section{Naskah Nusantara sebagai Kekayaan Intelektual Bangsa}

Sebelum budaya naskah (tulis) berkembang di Indonesia, awalnya didahului oleh budaya bertutur/budaya oral yang disampaikan secara turun temurun pada tiap generasi. Sisa budaya oral ini sampai sekarang masih dilakukan di beberapa wilayah Indonesia. Sesuai dengan perjalanan waktu para leluhur menciptakan simbol-simbol sederhana cara berkomunikasi yang nantinya berkembang menjadi budaya baca tulis. Pada saat budaya baca tulis mulai berkembang, simbol-simbol tersebut akhirnya menjadi bentuk aksara, kemudian ketika proses interaksi kultural terjadi secara intensif pada masa berikutnya dan memunculkan bentuk aneka tulisan Nusantara.

Kehidupan budaya oleh leluhur bangsa Indonesia 'direkam' dalam naskahnaskah tua yang sangat beragam. Naskah-naskah tua itu tersebar hampir diseluruh wilayah kepulauan Nusantara. Hal itu membuktikan bahwa bangsa Indonesia purba adalah bangsa yang telah memiliki budaya tulis, bahkan mampu menuangkan semua ide, pikiran dan gagasannya dalam bentuk tulisan.

Artifak budaya tulis tersebut tertuang dalam media yang terbuat dari batu, daun lontar, daun nipah, bambu, rotan, kulit kayu, logam, kain dan kertas daluwang. Sayang sekali iklim yang kurang mendukung, kelembaban udara, binatang pengerat dan mereka yang kurang menghargai warisan yang tidak ternilai ini, menyebabkan kerusakan, kehilangan dan bahkan punahnya naskah tua tersebut. Kondisi sebagian naskah tersebut sangat menyedihkan, apabila tidak ada upaya untuk merawat dan memahami nilai-nilai yang terkandung didalamnya serta 
keinginan untuk mensosialisasikannya, dikhawatirkan dikemudian hari generasi muda dimasa datang tidak akan pernah mengenalnya ${ }^{[9]}$.

Pada masa pemerintahan kolonial, sekitar tahun 1800-an salah seorang gubernur Belanda yang mempunyai perhatian akan pentingnya naskah-naskah tua Nusantara kemudian berinisiatip mengumpulkan dan menulis ulang naskahnaskah tua itu. Petinggi Belanda yang berjasa mengumpulkan naskah-naskah tua tersebut bernama Gubernur Jendral Baron Van der Cappelen (Voorhoeve, 1964:258). Sebagian besar naskah-naskah yang berhasil dikumpulkan dan ditulis ulang masih terjaga di Musium Perpustakaan Nasional Jakarta. Menurut data-data yang terdapat di Musium Perpustakaan Nasional yang ditulis ulang dengan rata-rata berusia lebih dari seratus tahun., sedangkan naskah-naskah tua yang lebih tua diperkirakan ada yang dibuat pada abad ke 15 sampai awal abad ke 18.

Ketertarikan para budayawan, kaum intelektual dan ahli sejarah di Eropa ditunjukkan oleh banyaknya hasil penelitian tentang naskah-naskah tua Indonesia yang telah dilakukan sejak 200 tahun yang lalu secara individu. Di Pusat penelitian Prancis (Universitas Sorbonne) dan Belanda (KITLV-Leiden University) tercatat banyak saduran naskah tua Indonesia yang baik merupakan hasil penelitian, disertasi ataupun interpretasi yang ditulis oleh pakar sejarah, antropolog dan sosiolog asing. Hal ini menjadi ironi karena belum banyak nama ilmuwan Indonesia yang meneliti naskah-naskah tua peninggalan leluhurnya sendiri. Tercatat hingga tahun 1960 an hanya beberapa nama orang Indonesia yang meneliti naskah Nusantara, itupun masih didampingi peneliti asing.

\section{$3 \quad$ Kedudukan Naskah Naskah Tua Nusantara}

Naskah-naskah tua Nusantara tersebar di seluruh wilayah Indonesia, sebagian besar ditulis dalam bahasa daerah yaitu: Melayu, Sunda, Jawa, Bali, Batak, Lampung, Bugis, Makasar, Madura dll. Sedangkan huruf/aksara yang dipakai adalah aksara daerah yaitu huruf Batak, Lampung, Rencong, Bugis, Makasar, Jawa Kuno, Sunda Kuno, Bali, Arab Jawi/Jawa dan Arab Pegon/Melayu. Sebagian lainnya dalam huruf Palawa. Perlu diingat naskah-naskah Nusantara itu sebagian besar tidak bergambar (ilustrasi), hanya sebagian kecil saja yang memuat ilustrasi dan iluminasi. Dari sebagian naskah yang bergambar itulah terlihat bahwa nenek moyang bangsa Indonesia telah memiliki tradisi visualisasi yang unik dan mempesona. 


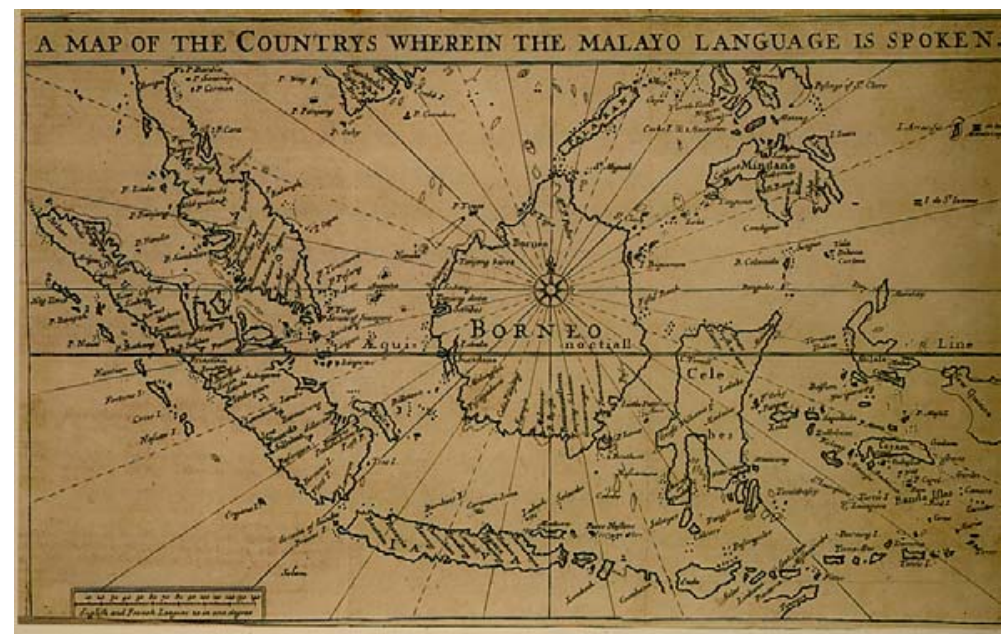

Gambar 1 “Peta Kepulauan Nusantara” (Sumber: A Dictionary English Malayo, Malayo-English, Britis Library, Thomas Bowrey 1701; Dlm: Golden Letters, Writing Traditions of Indonesia).

Hasil penelitian menunjukkan fakta, bahwa bahasa Melayu pernah menjadi bahasa pengantar di kawasan Asia, bahkan dipakai untuk sarana berkomunikasi, baik diplomasi politik, perdagangan, atau komunikasi antar bangsa. Pada tahun 1614 di Inggris telah diterbitkan kamus Melayu-Inggris yang menjadi pedoman bagi pedagang Eropa yang melakukan hubungan dagang dengan Asia Timur, hal ini menggambarkan betapa strategisnya Indonesia, hal itu ditunjukkan pentingnya untuk memahami bahasa Melayu jika ingin melakukan kontak dagang dan menjalin hubungan budaya dengan bangsa-bangsa di Asia Tenggara, khususnya wilayah Nusantara pada masa itu ${ }^{[1]}$.

Dari naskah-naskah tua Nusantara dapat diperoleh informasi bagaimana transfer ilmu secara turun-temurun telah dilakukan oleh nenek moyang kita sejak berabad-abad. Saat ini pembuatan naskah secara tradisional masih dilakukan dan dikerjakan pada daun lontar di Bali,dan masih merupakan living tradition. Namun fungsinya telah bergeser hanya untuk konsumsi wisata ${ }^{[9]}$. Hal ini terjadi juga dibeberapa wilayah Sumatra, Jawa, Sulawesi, dan Indonesia bagian Timur lainnya

\section{$4 \quad$ Naskah-Naskah Tertua di bumi Nusantara}

Primadi Tabrani, pakar bahasa rupa menuturkan bahwa gua pra sejarah dapat dikatakan sebagai perpustakaan pertama yang dibuat oleh manusia, jadi naskah adalah gua prasejarah itu sendiri. (Tabrani:1991). Gambar-gambar pada cadas menginformasikan pesan bahwa di sana pernah hidup masyarakat yang memiliki mata pencaharian berburu binatang, menangkap ikan di laut, 
menterakan cap tangan dan sudah mampu menggambarkan keberadaannya pada gua cadas.

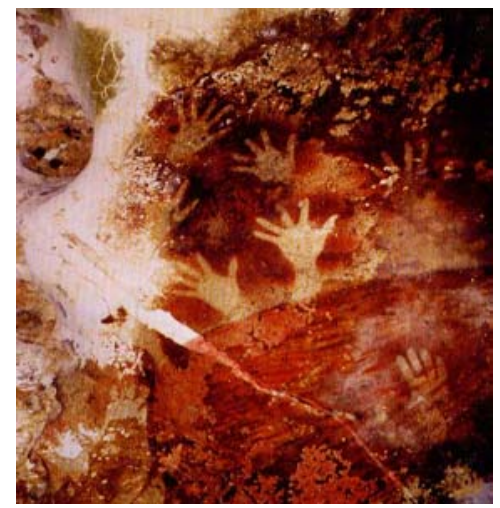

Gambar 2 Gambar Gua Prasejarah Telapak Tangan,Gua Leang-Leang, Desa Maris, Sulawesi selatan. 10.000 SM-6.000 SM (Koleksi Foto: Primadi Tabrani).

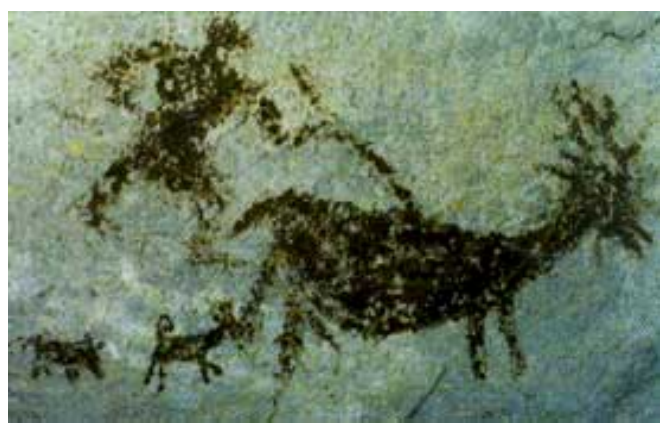

Gambar 3 Gambar Gua Prasejarah di Kep. Key Maluku 6.000 SM-5.000SM (Koleksi Foto : Primadi Tabrani).

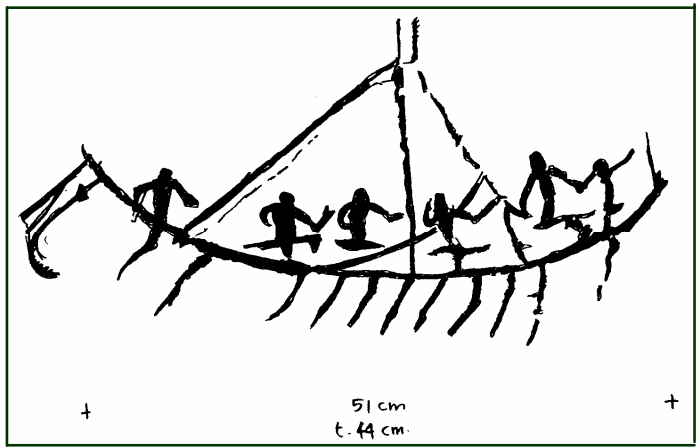

Gambar 4 Gambar Gua Pra Sejarah di Gua Muna, Kalimantan 10.000 SM6.000 SM (Koleksi Foto: Primadi Tabrani). 
Naskah Nusantara berupa prasasti, yang dianggap tertua di Indonesia ditulis dalam huruf Palawa Tua pada batu kira-kira tahun 400 M ditemukan di Kutai Kalimantan Barat dan tahun 450 M Ciaruteun Jawa Barat yang kemudian dikenal sebagai Prasasti Batu tulis Bogor, pada permukaan batu terdapat tulisan dan cap sepasang telapak kaki manusia.

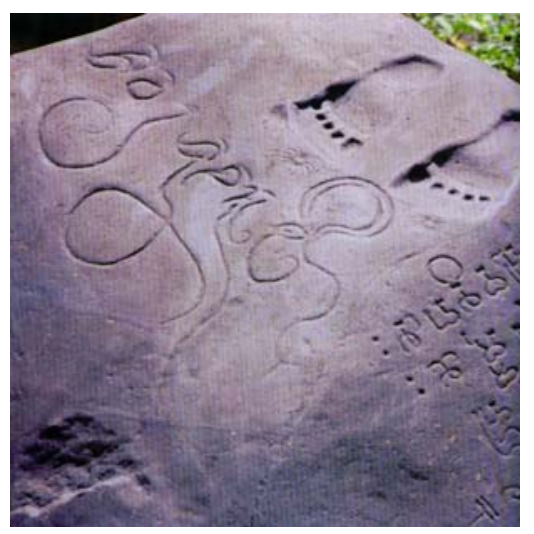

Gambar 5 Prasasti Ciaruten, Cap Kaki Raja Purnawarman, $\_400$ M, Batu Tulis Bogor, Jawa Barat (Sumber: Aksara,Indonesia Indah).

Selain itu, ditemukan pula naskah yang dibuat pada tahun $684 \mathrm{M}$ di Talang Tuo Sumatra Selatan. Selanjutnya terdapat naskah yang ditulis dalam huruf Palawa muda di atas perunggu yang dilapisi logam emas sebagai peninggalan masa kerajaan Sriwijaya thn $671 \mathrm{M}$.

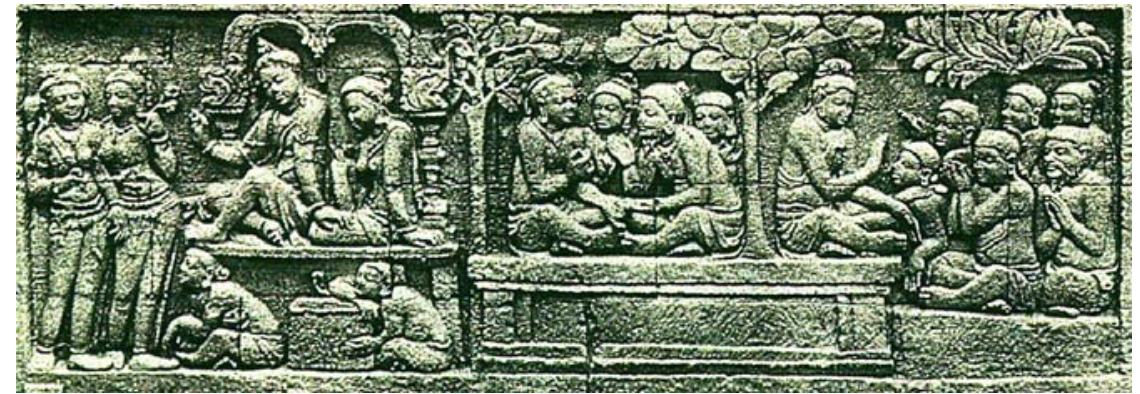

Gambar 6 Relief candi Borobudur (Koleksi Foto:Haryadi Suadi).

Naskah Nusantara yang bersifat monumental dimasa Hindu-Budha adalah relief di candi Borobudur yang mengilustrasikan perjalanan Budha Gautama. Candi ini dikenal sebagai tempat kegiatan ritual ajaran Budha, dibuat antara tahun 700 - 950 M di masa dinasti Sailendra, aksara yang dipergunakan huruf Kawi (Jawa kuno ). 
Hingga di abad 11, di wilayah Nusantara umumnya naskah yang dibuat di atas permukaan batu dan logam. Sebagian di antaranya ditemukan naskah yang dibuat pada kulit binatang, tulang, kayu, kulit kayu, bambu dan rotan , terutama naskah yang ditemukan di wilayah Sumatra dan Sulawesi.
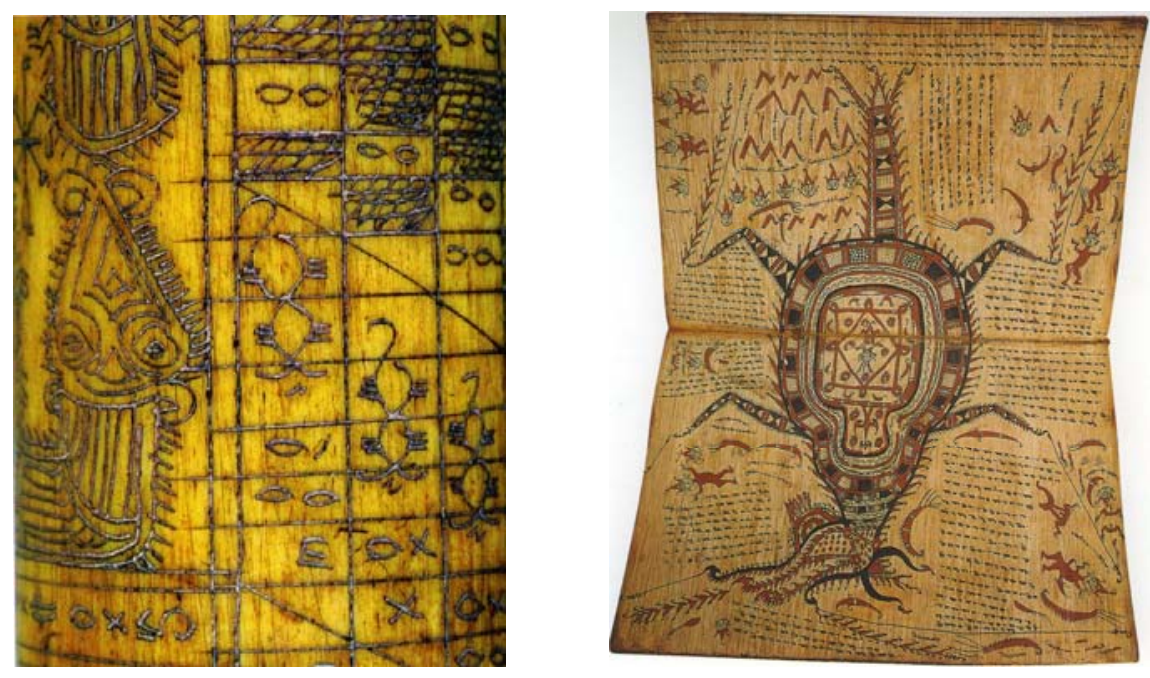

Gambar 7 (a) Naskah Pustaha Mantra dan Racikan obat, ditoreh dengan huruf Batak Kuno, pada permukaan Tulang, (b) Naskah Pustaha Mantra dan ramalan, ditoreh dengan huruf Batak Kuno, pada permukaan kulit kayu (Sumber: koleksi foto: Yayasan Lontar).

Sedangkan naskah yang dibuat pada permukaan daun nipah, daun lontar terutama banyak ditemukan di wilayah Jawa dan Bali.

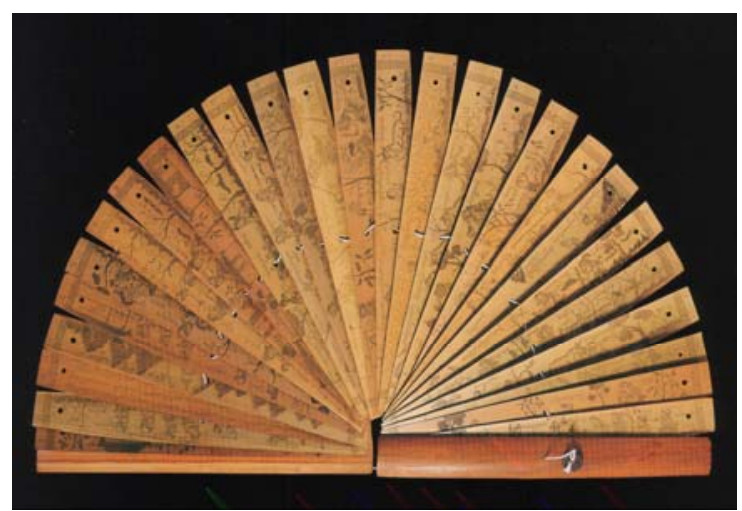

Gambar 8 Naskah Kakawin Arjuna Wiwaha, karya Empu Kanwa, Abad XI, ditoreh pada Lontar dengan huruf Bali Kuno (Sumber: Museum Sono Budoyo, Jogyakarta) 


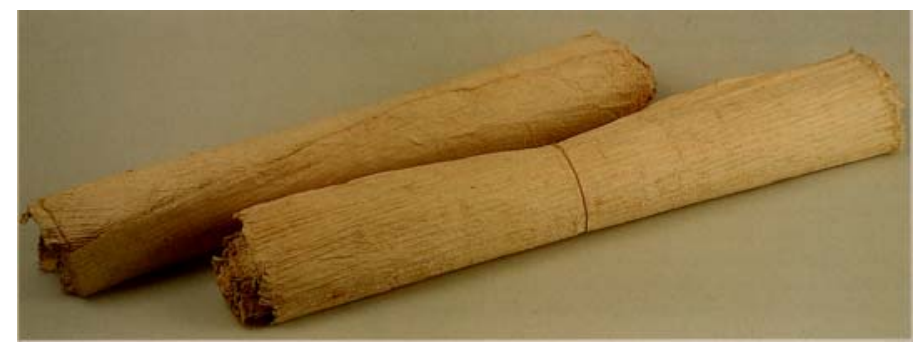

Gambar 9 Kertas Daluwang, dibuat dari kulit pohon Saeh (broussonetia papyfera) (Sumber: Illuminations, The Writing Traditions of Indonesia,1996)..

Di abad 12 - 19 M, mulai dikenal pemakaian kertas alam (daluwang). Naskahnaskah mulai ditulis pada kertas daluwang atau semacam kain, terutama ketika Islam mulai berpengaruh kuat di wilayah Nusantara. Naskah-naskah ini dikenal sebagai naskah yang kaya ragam bentuk, tema, dan indah secara bertahap menyebar ke seluruh wilayah Nusantara ${ }^{[9]}$.

\section{$5 \quad$ Jenis Naskah Tua Nusantara}

Naskah-naskah Nusantara yang berasal dari Sumatra, Jawa, Bali, Kalimantan, Sulawesi dan Nusa Tenggara. oleh T.E.Behrend dkk dalam katalog induk naskah Nusantara diklasifikasikan menjadi beberapa jenis dan katagori:

1. Naskah Sejarah. Naskah jenis ini mencakup segala macam Babad dan Panji (Jawa - Bali) yang memaparkan ceritera legenda penciptaan dunia, dan sejarah hingga abad 19.

2. Naskah Silsilah. Naskah yang menuliskan tentang silsilah para raja Nusantara.

3. Naskah Hukum. Naskah ini memuat hukum, peraturan dan adat istiadat kerajaan serta adat istiadat masyarakat dimasanya di berbagai wilayah Nusantara,

4. Naskah Sastra. Kebanyakan naskah ini berupa prosa dan puisi dan memiliki pakem (aturan), isinya banyak menceritakan tentang peristiwa yang terjadi pada zaman itu. Di Jawa dan Bali dipaparkan dalam bentuk macapat (pupuh) sangat dipengaruhi oleh lakon-lakon wayang.

5. Naskah Piwulang. Naskah ini memuat tentang ajaran para wali, orang saleh, suci dan bijaksana. Di Jawa dan Bali kenal dengan nama Suluk sebagai sastra kebijaksanaan, ajaran tersebut sebagian memuat filsafat agama Islam dan kepercayaan setempat.

6. Naskah Islam. Naskah ini sarat dengan tafsir Al Quran, yang memuat tentang fikih, aturan dan hukum Islam, kebanyakan teks ditulis dalam huruf Arab Pegon, juga terdapat penulisan tentang riwayat hidup para nabi (Serat Ambiya). 
7. Naskah Primbon. Naskah ini memuat berbagai macam ramalan dan ilmu falak, juga sistim penanggalan (kalender), untuk menentukan hari baik, hari buruk manusia ketika akan melakukan sesuatu, naskah sejenis ini di Jawa dan Bali dikenal dengan nama Pawukon yang hingga kini masih banyak dipakai sebagai pegangan .

8. Naskah Ilmu Bahasa. Naskah ini memuat tentang tata bahasa dan kesusastraan serta kamus bahasa.

9. Naskah Musik. Naskah ini memuat notasi-notasi nada dari berbagai peralatan musik tradisi Nusantara, seperti notasi gendhing gamelan Jawa.

10. Naskah Tari-tarian. Memuat tentang seni tari , seni bela diri dan seni gerak

11. Naskah Adat Istiadat. Naskah ini memuat berbagai hal yang berkaitan dengan adat istiadat setempat, kebiasaan, bentuk kerajinan, tata krama rakyat kecil hingga bangsawan, termasuk juga tata cara berpakaian dan tata cara upacara .

12. Naskah Ilmu Pengetahuan. Naskah dalam katagori ini adalah naskah yang memuat tentang berbagai ilmu pengetahuan seperti kedokteran tradisional, biologi, obat-obatan tradisional, naskah permainan anak, cerita rakyat, fabel dan informasi tentang berbagai macam hal di luar naskah sebelumnya yang telah diuraikan di atas.

\section{Ragam Visual Ilustrasi pada Naskah Nusantara}

Wujud dan bentuk visual naskah sangat beragam, masing masing wilayah memiliki karakter yang berbeda dan unik sesuai dengan lingkungan, potensi geografis dan budayanya. Secara umum naskah dipahami sebagai artefak yang menjadi wilayah kajian Filologi yang khusus mempelajari teks, dan Arkeologi yang mempelajari artifak. Artifak naskah-naskah tua Nusantara dalam penelitian ini khususnya mengkaji dari sudut pandang ilmu seni rupa. Dari hasil rekaman data visual yang terkumpul yang dapat dilihat beberapa diantaranya adalah sebagai berikut:

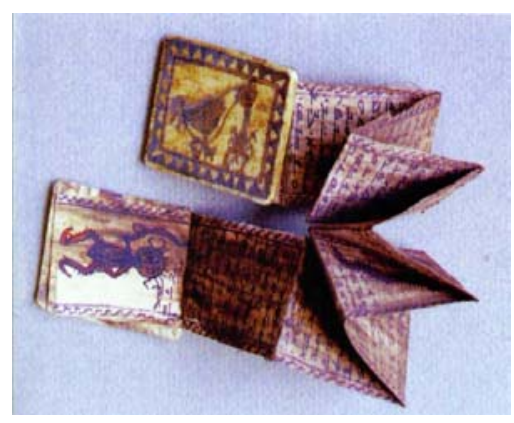

Gambar 10 Naskah Pustaha Batak, ditorehkan pada kulit kayu dengan huruf Batak Kuno (Koleksi Museum Perpustakaan Nasional Jakarta). 


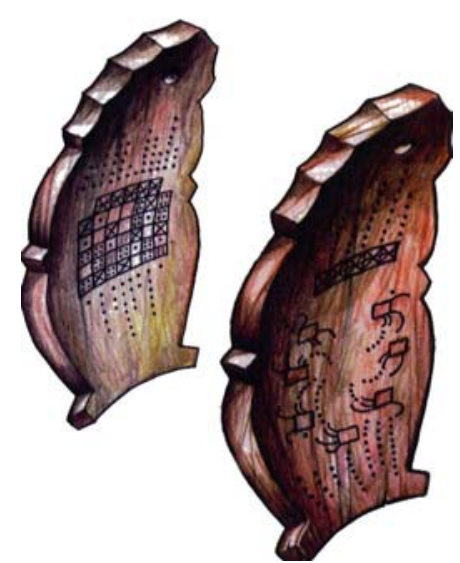

Gambar 11 Naskah Kolenjer, Penanggalan suku Baduy, Jawa Barat, memuat pasaran untuk menentukan hari baik dan buruk, ditoreh pada lempengan kayu. (Koleksi Museum Perpustakaan Nasional Jakarta)
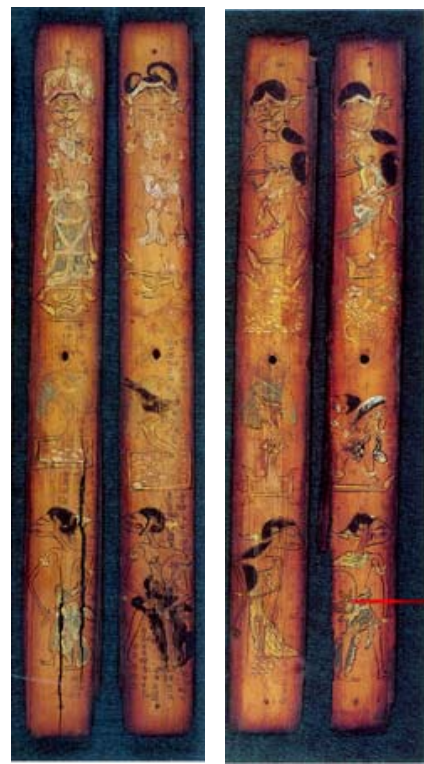

Gambar 12 Gambar Wayang pada permukaan kayu (Koleksi: Museum Perpustakaan Nasional Jakarta).

Dilihat dari segi visual, aspek keragaman tampak dari bentuk, gaya ungkap gambar yang diekspresikan oleh masing-masing suku, dan hal itu merupakan cerminan tradisi kehidupan sosial budaya masyarakat dan sumber daya alam setempat. Sebelum ditemukan kertas naskah terbuat dari beragam bahan dan dibuat dengan teknik yang disesuaikan dengan cara memperlakukan material itu sendiri. Naskah-naskah tua di beberapa wilayah Indonesia umumnya 
mempergunakan media batu dan kayu. Perbedaan media itu menyebabkan teknik dan penggarapan berbeda demikian pula wujud visualnya.

Material batu bersifat keras dan kasar sehingga harus dipahat atau ditatah seperti arca, prasasti dan relief, sedangkan pada material tulang, kayu/kulit kayu atau kulit binatang bisa ditoreh, dicukil, dikelupas atau teknik bakar. Perkembangan ini terjadi hampir disetiap etnik Nusantara, latar belakang budaya setempat menyebabkan masing-masing naskah memiliki keunikan, baik dari segi penampilan maupun reka rupa dan reka bentuknya. Ketika budaya kertas mulai berkembang media kertas mulai dipergunakan dalam pembuatan naskah, teknik dan penggarapan mengalami perkembangan, meskipun demikian cara menggambarkan masih mempergunakan tata atur yang sama seperti pada media batu ataupun kayu.(Sedyawati dlm Aksara,Indonesia Indah:1991)

\section{$7 \quad$ Ilustrasi dan Iluminasi dalam Naskah Tua Indonesia}

Selama ini ilustrasi sebagai bagian dari sebuah naskah masih dipahami sebagai pendukung tulisan yaitu sebagai interpertasi yang berkaitan dengan isi teks. Fungsinya dipahami hanya untuk lebih memperjelas teks saja. Demikian pula pemahaman gambar iluminasi tidak lebih hanya sebagai unsur pendukung keindahan/estetik dan penampilan wujud naskah..

Bila dikaji lebih cermat mengenai bentuk objek, warna, ukuran, komposisi dan simbol-simbol yang digambarkan mengandung nilai-nilai yang unik.

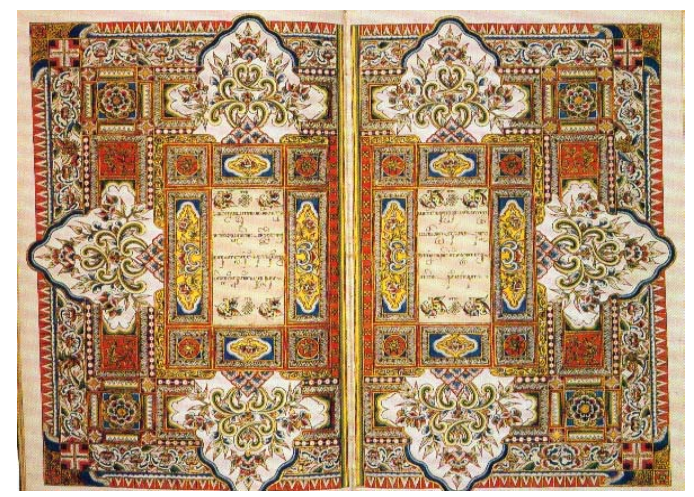

Gambar 13 Serat Ramayana Kawi, ditulis dengan huruf Jawa Kuno pada kertas (31X19,5 cm), 1830 (Koleksi Royal Asiatic Society, Raffles Java, UK).

Berdasarkan tata ungkap gambar, tersuratlah sebuah konsepsi rupa berupa tata cara menggambar, cara berungkap dan mengkomunikasikan sesuatu pesan, sebagai simbol yang memiliki arti. Ilustrasi dan iluminasi merupakan sebuah 
bahasa khusus yang memiliki fungsi tertentu untuk dipahami masyarakat pada masanya.

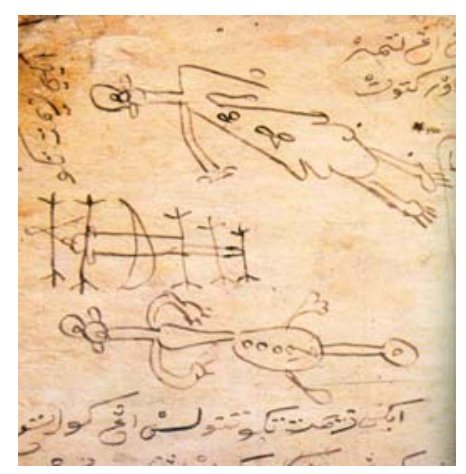

Gambar 14 Naskah Layang Kawruh, Naskah Sunda,memuat ajaran budi pekerti dalam Islam, ditulis pada kertas Daluwang $(45 X 18,5 \mathrm{~cm})$ (Koleksi Museum Sri Baduga, Bandung, Jawa Barat).

\section{$8 \quad$ Fungsi Sosial Naskah Nusantara}

Uraian di bawah ini memberi gambaran awal tentang wujud visual ilustrasi dari berbagai naskah Nusantara dan sebagian besar adalah gambar ilustrasi pada naskah Jawa dan Bali, karena naskah Jawa dan Bali masih terdokumentasi dengan baik jika dibandingkan koleksi naskah dari wilayah lainnya. Beberapa gambar ilustrasi pada naskah tua ini memberikan gambaran kekayaan dan beragamnya konsepsi seni rupa dan nilai-nilai estetik tradisi serta budaya berfikir masyarakat Indonesia dalam menuangkan ekspresi dalam berkesenian.

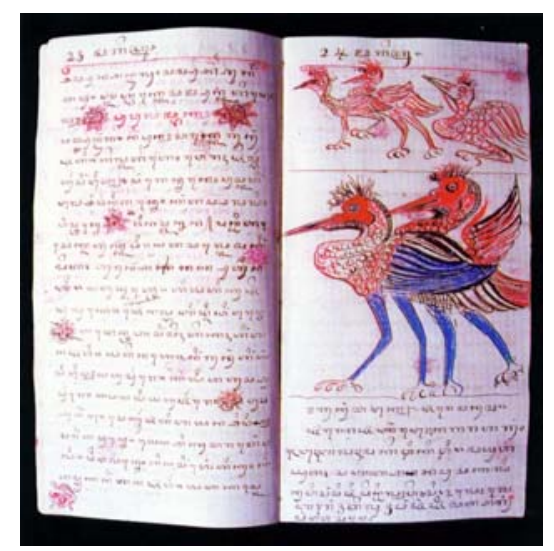

Gambar 15 Naskah Paririmbon Sundatahun 1900, memuat ramalan dan panduan menentukan hari baik dan buruk dalam mengerjakan sesuatu, ditulis pada kertas. (Koleksi Museum Sri Baduga, Bandung, Jawa Barat). 


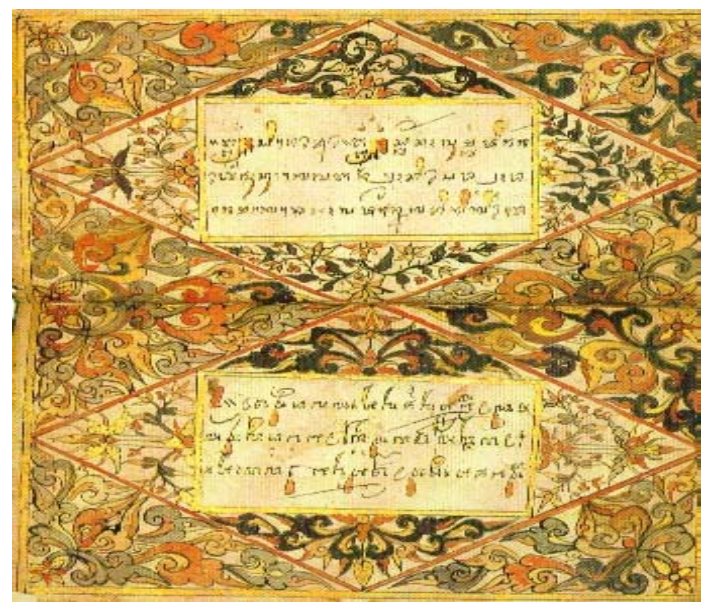

Gambar 16 Naskah Jawa di Palembang, berupa Puisi yg ditulis dengan huruf Arab Melayu, 1830 (Koleksi Royal Asiatik Society, Raffles Java, UK).

Proses penciptaan ilustrasi pada naskah tua merupakan kegiatan 'berkesenian' yang berkesinambungan dengan seni tradisi dan tampaknya sudah terpola dalam budaya masyarakat Nusantara sejak dahulu. Konsepsi-konsepsi yang melandasi penciptaan ilustrasi pada naskah tua Nusantara tersebut adalah sebagai berikut:

1. Wujud visual gambar Ilustrasi pada naskah memiliki metoda tertentu yang mengandung sejumlah nilai, norma, aturan dan falsafah hidup sebagai manifestasi dari perwujudan daya cipta masyarakat.

2. Wujud visualnya merupakan representasi dari nilai-nilai dan aturan-aturan tertentu yang terkait dengan proses penciptaan suatu produk seni rupa tradisi.

3. Ilustrasi pada naskah mempunyai fungsi Sosial sebagai media komunikasi yang terkait dengan sistem nilai, pranata sosial dan budaya pada masanya bahkan masih dijadikan pedoman masyakat Nusantara hingga sekarang.

4. Faktor-faktor enkulturasi, akulturasi, sinkretisme, asimilasi yang disebabkan oleh persilangan budaya asing turut memberikan ciri-ciri khusus terhadap wujud visual gambar Ilustrasi pada Naskah Tua Nusantara, baik dilihat dari persamaannya maupun perbedaannya. Mengingat posisi strategis negara Indonesia yang terletak diantara dua benua dan menjadi tempat persinggahan antar bangsa yang menyebabkan terjadinya proses silang budaya dan globalisasi sejak berabad-abad. Naskah Tua Nusantara adalah gambaran transformasi dalam budaya baca tulis dan seni rupa.

5. Ilustrasi pada Naskah Tua Nusantara memuat nilai-nilai spiritualitas yang mencerminkan masyarakatnya adalah masyarakat beragama yang memiliki keyakinan tentang ke Tuhanan. 


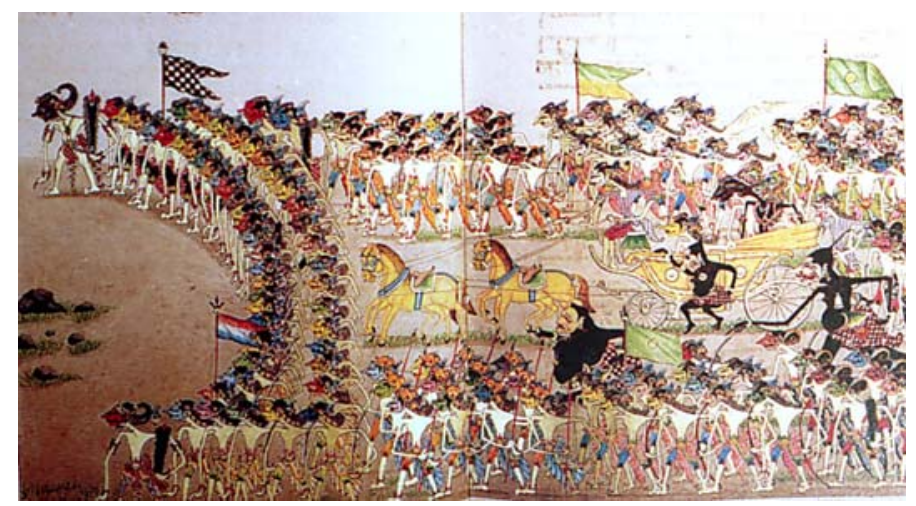

Gambar 17 Serat Bharatayudha, 1902-1903 (Sumber: Museum perpustakaan Widya Budaya, Keraton Yogyakarta).

\section{Ragam Ilustrasi pada Naskah Tua Jawa Periode Tahun 1800- 1900an}

Gambar-gambar ilustrasi naskah Nusantara di Jawa yang paling tua memperlihatkan kedekatan dengan gambaran-gambaran seni rupa pra Hindu adalah gaya gambar rajahan. Dengan demikian gambar rajahan adalah bentuk 'ilustrasi asli' masyarakat Jawa, yang belum banyak terpengaruh oleh budaya asing. Pada masa klasik Hindu-Budha gambar rajahan mengalami perubahan dengan munculnya perupaan tokoh-tokoh pewayangan dan digambarkan dalam bentuk anatomis seperti yang terlihat pada relief-relief candi.

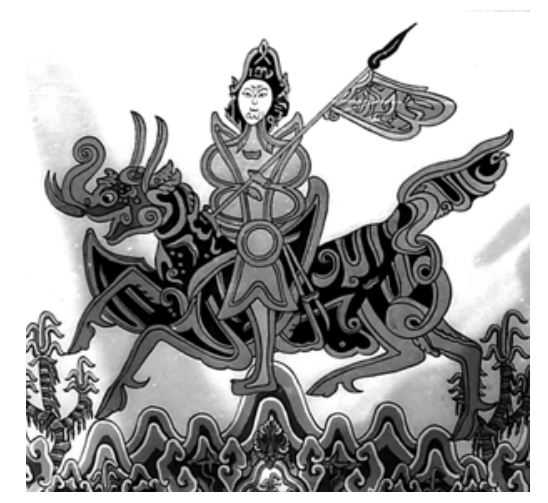

Gambar 18 Kaligrafi Arab dibentuk menjadi orang naik kuda (Cirebon).

Pada masa Islam di wilayah Nusantara, gambar rajahan cenderung lebih abstrak dan memunculkan kaligrafi Arab, hal itu berkembang sampai sekarang. Kemudian mengalami perubahan dimasa pemerintahan kolonial Belanda dengan paduan dengan bentuk ikonik Barat. 
Gaya visual pada naskah yang terdapat di Jawa sekitar tahun 1800 - 1900 an, awalnya tampak melalui penyederhanaan gaya penggambaran objek yang diadopsi dari relief candi Panataran. Ciri gambar tradisional Jawa tersebut mengandung kemiripan dengan penggambaran wayang kulit. Penggambaran objek gambar ,baik manusia, binatang, tumbuhan dan benda-benda lainnya ditampilkan sepenuhnya utuh, sedangkan manusia dan hewan digambar dari arah samping dan benda-benda lainnya digambar dari pelbagai sudut pandang.

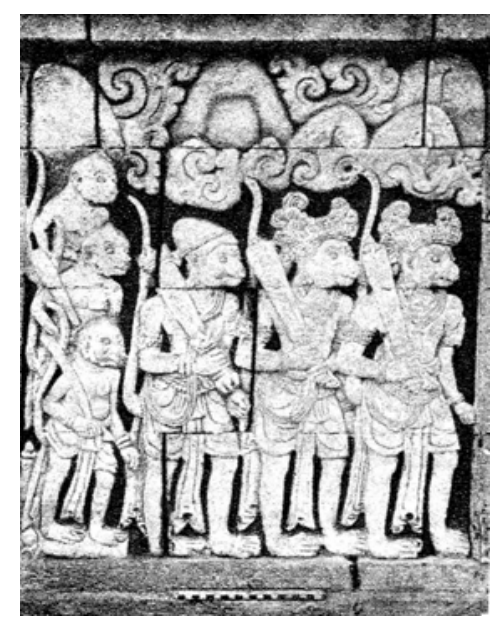

Gambar 19 Relief Candi Pantaran (Koleksi: Haryadi Suadi).

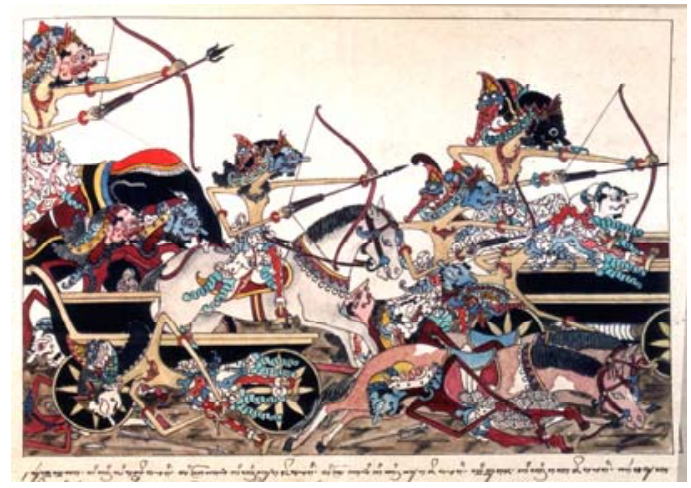

Gambar 20 Serat Prang Bharatayudha, 1893 (Koleksi Museum Sana Budaya Jogyakarta).

Para seniman tradisional Jawa mulai menggunakan menggambar cara 'barat' diperkirakan pada akhir 18, namun masih berunsur spiritualitas Hindu. Hal itu dicirikan dengan hadirnya gambar tokoh-tokoh pewayangan Mahabharata, padahal saat itu kebudayaan Islam mulai mengakar kuat di Jawa. 


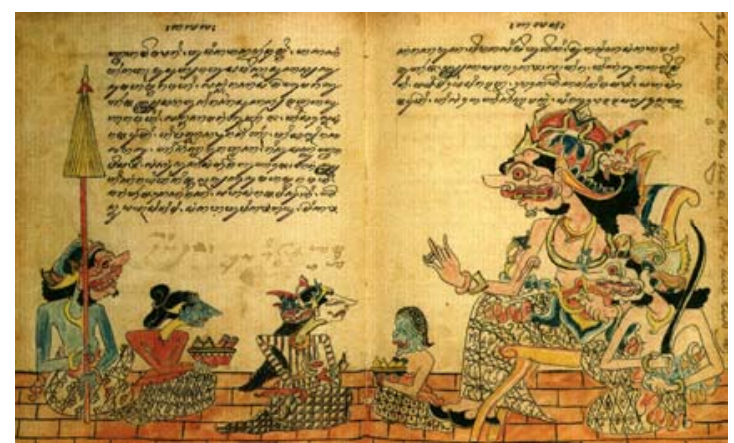

Gambar 21 Serat Ki Asmarasupi, 1893 (Koleksi foto Yayasan Lontar).

Meskipun kebudayaan Barat mulai memasuki tanah air melalui proses kolonialisasi, para 'seniman' pada masa itu tidak meniru gaya Barat sepenuhnya, hal itu dibuktikan terjadinya proses adaptasi dan pengolahan bentuk, diwujudkan kembali berdasarkan interpretasi para penggambarnya. Proses tersebut menghasilkan suatu gaya baru yang berbeda dengan gaya sebelumnya akan tetapi tetap kaya dengan muatan lokal ke- Jawa-an seperti terlihat pada gambar di bawah ini yang menunjukkan pengaruh gaya menggambar cara Barat mulai mempengaruhi 'seniman-seniman' Jawa masa sekitar tahun 1800-an ${ }^{[19]}$.

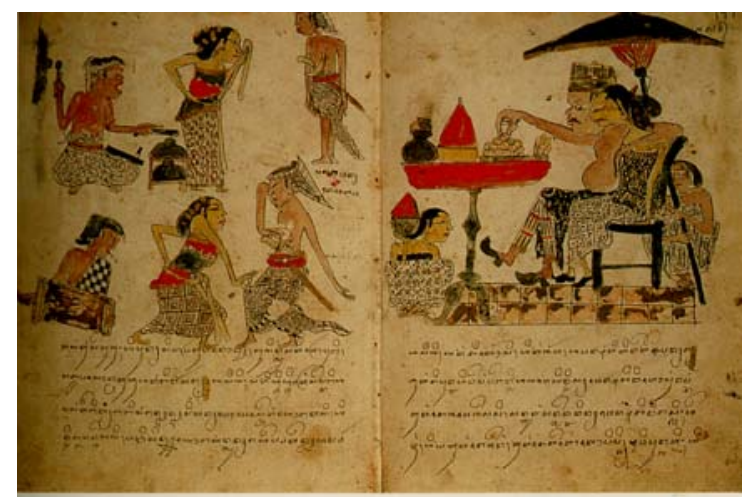

Gambar 22 Serat Damar Wulan, 1815 (Koleksi British Library, London, dari dari.Golden Letters, Writing Tradition of Indonesia.1991).

Hal penting lainnya adalah sejak terjadinya pengambil alihan kekukuasaan tanah Jawa oleh Inggris tahun 1811-1815, pemerintah kolonial Inggris melakukan pendekatan terhadap penduduk pribumi melalui hubungan diplomatik antara raja-raja Jawa dan kerajaan Inggris. Ketika wilayah Jawa dikembalikan kepada pemerintah kolonial Belanda, pendekatan itu tetap dijalankan. Pada masa inilah kebudayaan Eropa mulai diadopsi oleh seniman di 
Jawa. Para juru gambar pribumi, bersikap terbuka terhadap masuknya kebudayaan Barat, yang ditandai oleh upaya-upaya untuk mempelajari teknik menggambar Barat, seperti teknik perspektif maupun gaya menggambar Barat [19].

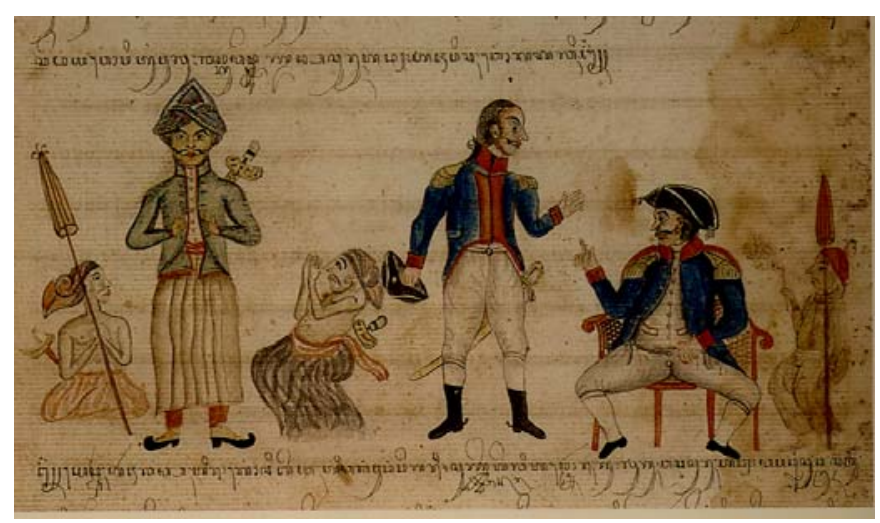

Gambar 23 Serat Raja Blambangan, 1774 (Koleksi Museum Perpustakaan Nasional, Jakarta).

10 Muatan Spiritualitas pada Ilustrasi di Jawa Periode Tahun 1800 - 1900 an.

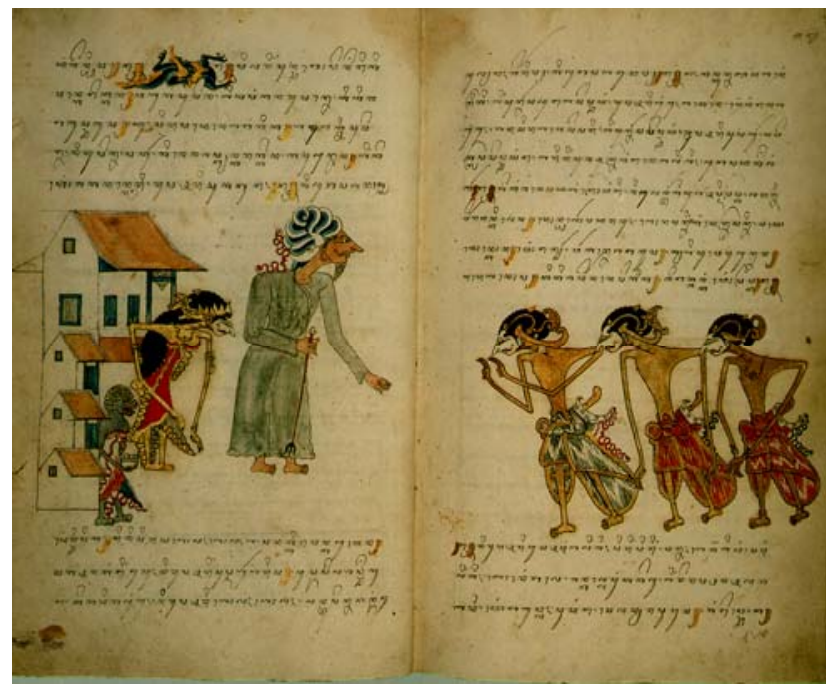

Gambar 24 Serat Selarasa, 1804, Gambaran Pangeran Selarasa sedang menghadap ulama yang kelak menjadi guru dalam mencari ilmu dan agama. (Koleksi Mc.Kenzie, British Library, London, dalam.Golden Letters, Writing Tradition of Indonesia, 1991). 
Di Jawa pada periode tahun 1800 - 1900 an pencarian nilai-nilai kehidupan terungkap dalam ilustrasi naskah-naskah tua yang diciptakan oleh para senimannya. Meskipun terjadi perubahan wujud visual pada gambar ilustrasi, baik konsep, tema, bahasa rupa maupun medium yang dipergunakan, namun hal tersebut merupakan sesuatu kekuatan budaya dan spiritualitas bangsa yang selalu hidup yang mencari keseimbangan antara rohaniah dan kehidupan dunia. Dari hasil analisis terhadap gambar ilustrasi pada naskah tua Jawa dan Bali dapat ditarik kesimpulan bahwa nilai spiritualitas masih sangat kuat bertahan, hal itu merupakan sikap kultural dan spiritual manusia Jawa dan Bali.

\section{Daftar Pustaka}

[1] Arp, Bernard, Gallop, Anabel The. 1991. Golden Letters, Writing Tradition of Indonesia, the British Library, London and The Lontar Foundation, Jakarta

[2] Behrend, T.E. 1990. Katalog Induk Naskah-Naskah Nusantara, jilid 1, Museum Jogyakarta, Penerbit Jambatan dan Ford Foundation, Jogyakarta

[3] Bodrogi, Tibor. 1972. Art of Indonesia, New York Graphic Society Ltd. Greenwich, Connecticut.

[4] Chamber-Loir, Henri \& Fathurahman, Omar. 1999. Khazanah Naskah;Panduan Koleksi Naskah-naskah Indonesia Sedunia-World Guide to Indonesian Manucript Collection, Seri Naskah dan Dokumen Nusantara, Ecole Francaise d'Extreme-Orient \& Yayasan Obor Indonesia, Cetakan I, Jakarta.

[5] Holt, Claire. 1973. Art in Indonesia:Continuities and Change, New York, Ithaca,Cornell University Press.

[6] Hildawaty Soemantri. 1998. Introduction "Indonesian:The Art of Archipilago “, Dalam Indonesian Heritage. Vol.7 Visual Art, Singapore, Archipilago Press.

[7] Hooykaas C. 1923. Drawings of Balinese Sorcery Penerbit "Tuta Sub Aegide Pallas”.

[8] $\longrightarrow$ Tovernarij op Bali Magische Tekeningen, Penerbit "Tuta Sub Aegide Pallas.

[9] Kumar, Ann and Mc. Glynn, John H. 1996. Illuminations, The Writing Traditions of Indonesia, New York, Published by Weatherhill, Inc. with Lontar Foundation.

[10] Lombard, Dennys. 1996. Nusa Jawa: Silang Budaya, Jilid I, II, III, Gramedia, Jakarta.

[11] Pegeaud, T.H. 1962. Java The $14^{\text {th }}$ Century, a Study in Cultural History, Jilid IV, The Hafue, NY.

[12] Ilustrasi Nusantara, Riset ITB, 2006.

[13] Kats, J. 1923. Het Javaansche Tooneel - Wajang Poerwa, Batavia. 
[14] Lewis, Albert Buell. 1951. Decorative Art New Guinea, Dover Publication, Inc, New York.

[15] Mann, A.F.Ph. Ot en Sien. 1928. Pen. JB Wolters Groningen, Den Haag, Weltevreden.

[16] Mulyono, Sri. 1975. Wayang Asal Usul, Filsafat \& Masa Depannya Badan Penerbit Alda, Jakarta.

[17] NN, Naskah, Pawukon, koleksi perpustakaan Radyo Pustoko, Surakarta.

[18] NN. 1901. Boon's Geillustreerd Magazijn, Batavia.

[19] Nuning, Damayanti, Haryadi Suadi. 2005. NaturalismeBarat dalam Seni Rupa Tradisi Ilustrasi Jawa dan Bali Periode awal Abad 19- Awal Abad 20, RU-ITB.

Dwimatra. , Muatan Spitualitas pada Seni Rupa Tradisional

[21] R. Tanoyo. 1967. Primbon Djawa Pawukon Pen. Djaja Baja, Surabaja.

[22] Soeharto. 1997. Aksara, Indonesia Indah 9, Yayasan Harapan Kita,Perum Percetakan RI, Jakarta

[23] Sindhunata. 2003. Pawukon, Bentara Budaya, Museum Negeri Sonobudoyo, Jogyakarta.

[24] Tabrani, Primadi. 1998. Message From Ancient Walls, Bandung, Penerbit ITB.

[25] .1995. Belajar Dari Sejarah dan Lingkungan, Sebuah Renungan Mengenai Wawasan Kebangsaan dan Dampak Globalisasi, Penerbit ITB , Bandung. .1990. Meninjau bahasa Rupa Wayang Beber Jaka Kembang Kuning dari Telaah Cara Wimba dan Tata Ungkapan Bahasa Rupa Media Rupa Rungu Dwimatra Statis Modern Dalam Hubungannya Dengan bahasa Rupa Gambar Prasejarah , Primitif, Gambar Anak dan Relief Cerita Lalita Vistara Borobudur, Disertasi, FSRD, ITB Bandung. . 2005. Bahasa Rupa Pen. “Kelir” Bandung. 